Why Waco? 



\title{
Why Waco?
}

\section{Cults and the Battle for Religious Freedom in America}

\author{
James D. Tabor \\ and \\ Eugene V. Gallagher
}

UNIVERSITY OF CALIFORNIA PRESS

BERKELEY LOS ANGELES LONDON 
University of California Press

Berkeley and Los Angeles, California

University of California Press, Ltd.

London, England

(C) 1995 by

The Regents of the University of California

Library of Congress Cataloging-in-Publication Data

Tabor, James D., 1946-

Why Waco? : cults and the battle for religious freedom in America / James D. Tabor and Eugene V. Gallagher.

p. $\mathrm{cm}$.

Includes bibliographical references and index.

ISBN 0-520-20186-8 (alk. paper)

ISBN 0-520-20899-4 (pbk: alk. paper)

1. Koresh, David. 1 959-1 993 . 2. Branch Davidians.

3. Waco Branch Dividian Disaster, Tex., 1993.

4. Cults-United States.

I. Gallagher, Eugene V. II.Title.

BP605.B72 $T_{33} 1995$

$299^{\prime} .93$ - dc2o

Printed in the United States of America

$\begin{array}{lllllllll}08 & 07 & 06 & 05 & 04 & 03 & 02 & 01 & 00\end{array}$

$\begin{array}{lllllll}9 & 8 & 7 & 6 & 5 & 4 & 3\end{array}$

The paper used in this publication is both acid-frec and totally chlorine-free (TCF). It meets the minimum requirements of ANSI/ NISO Z $39.48-1992$ (R 1997) (Permanence of Paper). () 
For David P. Efroymson in friendship and gratitude for a quarter century of intellectual guidance and

for Jonathan Z. Smith, who taught both of us the importance of seeing ourselves in the light of the other and the other in the light of ourselves 

$A$ cult is a religion with no political power.

TOM WOLFF,

In Our Time 
